$\xi^{2}=-1$

\title{
Stochastic reservoir modelling for prospect mapping: a case study of "bright" field, Niger delta
}

\author{
James Sunday Abe ${ }^{1}$ *, Mary Taiwo Olowokere ${ }^{1}$, Pius Adekunle Enikanselu ${ }^{1}$ \\ ${ }^{1}$ Department of Applied Geophysics, Federal University of Technology Akure \\ *Corresponding author E-mail: jsabe@futa.edu.ng
}

\begin{abstract}
Deterministic reservoir modeling using geostatistical approach is inherently ambiguous because of the uncertainties contained in the generated reservoir models. Stochastic reservoir modelling using sequential gaussian simulation algorithm can resolve this problem by generating various realizations of petrophysical property models in order to map this uncertainties caused by subsurface heterogeneity. Suites of well logs for four wells with seismic data in SEG-Y format were used for this analysis. The wells were correlated and a reservoir was mapped across them in other to map their lateral extent, synthetic seismogram was generated in other to match the event on the seismic with that of the synthetic after carrying out a shift of $-12 \mathrm{~ms}$. Seismic to well tie was done to ensure that the horizons were mapped accurately. The structural maps generated and the wells were input that goes into the stochastic modelling process. Five realizations each of facies(lithology), effective porosity, total porosity, net to gross, volume of shale and one realization for permeability and water saturation were generated. The facies models showed the distribution of sand and shale with sand at the existing well locations and the effective porosity, total porosity, net to gross, volume of shale models showed excellent values around the well location. Permeability and water saturation models showed that the existing wells were drilled at the flank of the anticlinal structure. Two drillable points (prospects) were proposed by considering all the initial petrophysical property models and the parameters of the two points named P1 and P2 showed that they contain hydrocarbon in commercial quantity. Stochastic reservoir modelling has proved effective in mapping uncertainties and detecting bypassed hydrocarbons.
\end{abstract}

Keywords: Sequential Gaussian Simulation; Modeling; Geostatistics.

\section{Introduction}

Reservoir modeling is an important method for reservoir description, with the development of computer, the modeling of oil and gas reservoir has developed rapidly. In order to find out the distribution of the remaining oil in the old oil field and to further improve the level of exploration and development, the establishment of a more sophisticated three-dimensional geological model is highly essential (Xiangyang, 2001; Gongquan, 2006; Zhenfeng, 2003; Qihong, 2000; Xingyao, 2005).

The degree of reliability and precision of analyzing the geology of a sedimentary package can be greatly enhanced by integrating seismic data with well logs which, in some cases, have been used independently in hydrocarbon exploration and exploitation studies (Aizebeokhai and Olayinka, 2011; Jegede et al., 2014). The occurrence, distribution and character of hydrocarbon vary systematically as a function of the relative rate of hydrocarbon production and accommodation change (Abe and Olowokere 2013).

Stochastic simulation is a means of generating multiple equiprobable realizations of the property in question, rather than simply estimating the mean. Essentially, we are adding back in some noise to undo the smoothing effect of kriging (Geoff, 2005). This possibly gives a better representation of the natural variability of the property in question and gives us a means for quantifying our uncertainty regarding what's really down there. The two most commonly used forms of simulation for reservoir modeling applications are sequential Gaussian simulation for continuous variables like porosity and sequential indicator simulation for categorical variables like Facies (Geoff, 2005). Geostatistical reservoir-modeling technologies depart from the traditional deterministic modeling methods through consideration of spatial statistics and uncertainties. Geostatistical models typically examine closely the numerous solutions that satisfy the constraints imposed by the data. Using these tools, we can assess the uncertainty in the models, the unknown that inevitably results from never having enough data (PetroWiki, 2016). Stochastic modelling principles have become increasingly popular and many companies base their reservoir management on results from stochastic models. Several techniques are currently available (Dubrule, 1988; Haldorsen and Damsleth,1990; Omre,1991; Journel and Alabert,1990; Damsleth and Haldorsen, 1994). The focus is still on heterogeneity modeling, i.e. generating one or a few realizations which satisfies a geological interpretation and a set of specified data. There is, however, a growing use of stochastic models also in history matching (Tyler et al., 1993) and quantification of uncertainty both of volumes (Abrahamsen et al, 1991) and production (Omre et al, 1991; Lia et al, 1995).

Typically, the following data are used: well observations, spatial distributions of facies, petrophysics, and seismic horizons. The economic viability of a hydrocarbon field is also reliant on the quality and accuracy of lithology and pore fluid (Hami-Eddine et al., 2015). There has been an increased use of seismic data for both Facies and petrophysical modelling (Doyen, 1988). The crucial point is the correlation between the seismic and petrophysical variables. The correlation is probably significant in many reservoirs (Doyen, 1988) but is difficult 
to estimate. In addition there are some technical challenges related to the difference in scale between the seismic and petrophysical data. This research therefore involves generating realizations of the several petrophysical property models in order to assess their variation and predict other drillable areas.

\section{Location and geology of the study area}

The field is located within the onshore part of Niger delta. (Figure 1). The base map showed the location of the four wells and the seismic lines, a total of 673 inlines and 425 crosslines were interpreted. The field belongs to an active oil producing company in Nigeria. It covers an area extent of about $51,187 \mathrm{~km}^{2}$ and it lies within longitude $8.0^{\circ} \mathrm{E}$ to $8.3^{\circ} \mathrm{E}$ and latitude $4.0^{\circ} \mathrm{N}$ to $4.3^{\circ} \mathrm{N}$.

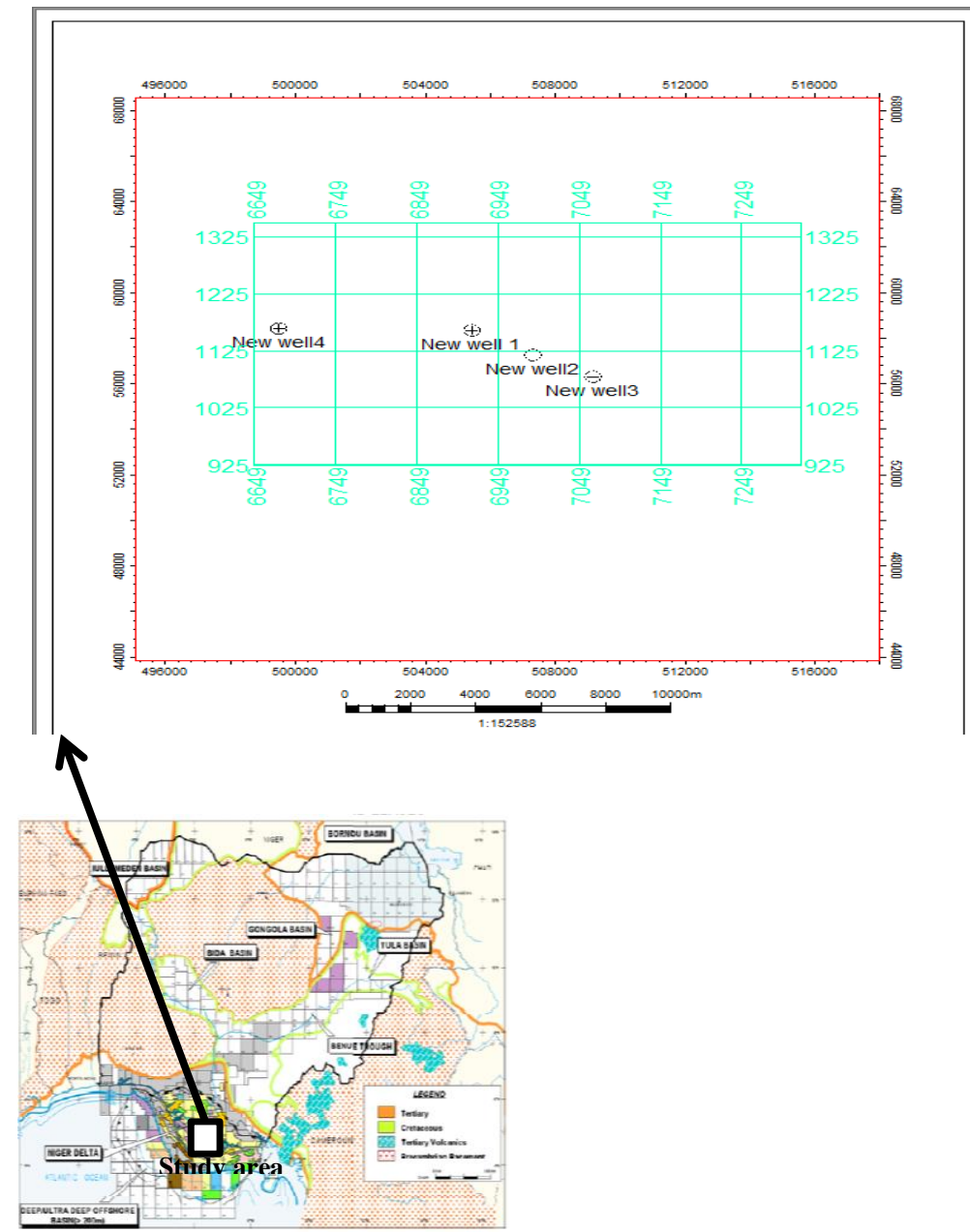

Fig. 1: Base Map and Map of Nigeria Showing the Study Area.

Niger Delta is a prolific hydrocarbon belt in the world. The formation of Niger Delta basin was initiated in the early Tertiary time. The Niger Delta is situated in the Gulf of Guinea and extends throughout the Niger Delta province. From the Eocene to the present, the Delta has prograded Southwest ward, forming depobelts that represent the most active portion of the Delta at each stage of its development (Doust and Omatsola, 1990).

Three lithostratigraphic units have been recognized in the subsurface of the Niger Delta (Short and Stauble, 1967; Frankl and Cordy, 1967 and Avbovbo, 1978). These are from the oldest to the youngest, the Akata, Agbada and Benin Formations (Figure 2). The Akata Formation (Eocene - Recent) is a marine sedimentary succession that is laid in front of the advancing delta and ranges from $1,968 \mathrm{ft}$ to $19,680 \mathrm{ft}(600-6,000 \mathrm{~m})$ in thickness. It consists of mainly uniform undercompacted shales with lenses of sandstone of abnormally high pressure at the top (Avbovbo, 1978). The shales are rich in both planktonic and benthonic foraminifera and were deposited in shallow to deep marine environment (Short and Stauble, 1967). The Agbada Formation (Eocene-Recent) is characterized by paralic interbedded sandstone and shale with a thickness of over 3,049m (Reijers, 1996). The top of Agbada Formation is defined as the first occurrence of shale with marine fauna that coincides with the base of the continental-transitional lithofacies (Adesida and Ehirim, 1988). The base is a significant sandstone body that coincides with the top of the Akata Formation (Short and Stauble, 1967). Some shales of the Agbada Formation were thought to be the source rocks, however; Ejedawe et al., (1984) deduced that the main source rocks of the Niger Delta are the shales of the Akata Formation. The Benin Formation is the youngest lithostratigraphic unit in the Niger Delta. It is Miocene Recent in age with a minimum thickness of more than $6,000 \mathrm{ft}(1,829 \mathrm{~m})$ and made up of continental sands and sandstones (>90\%) with few shale intercalations. The sands and sandstones are coarse grained, subangular to well rounded and are very poorly sorted. 


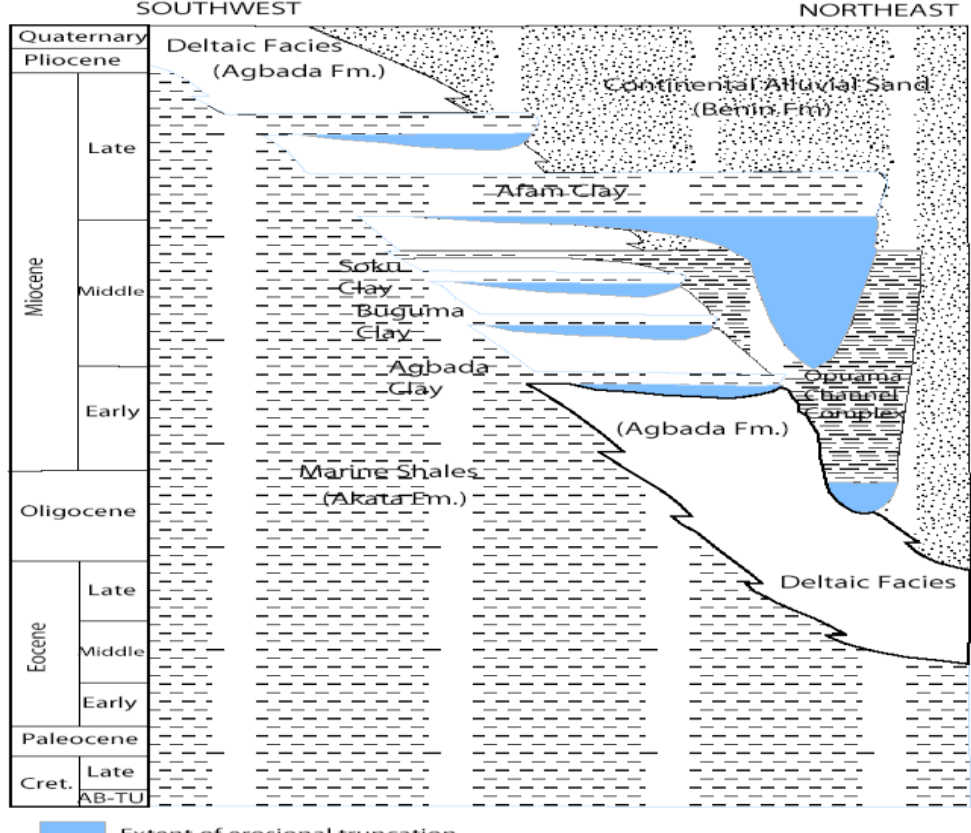

Fig. 2: Stratigraphic Column Showing the Three Formations of the Niger Delta. Modified from Shannon and Naylor (1989) and Doust and Omatsola (1990).

\section{Methodology}

The workflow used for the data analysis is as shown below in Figure 3. It involves three stages which are petrophysical analysis, seismic interpretation and reservoir modeling.

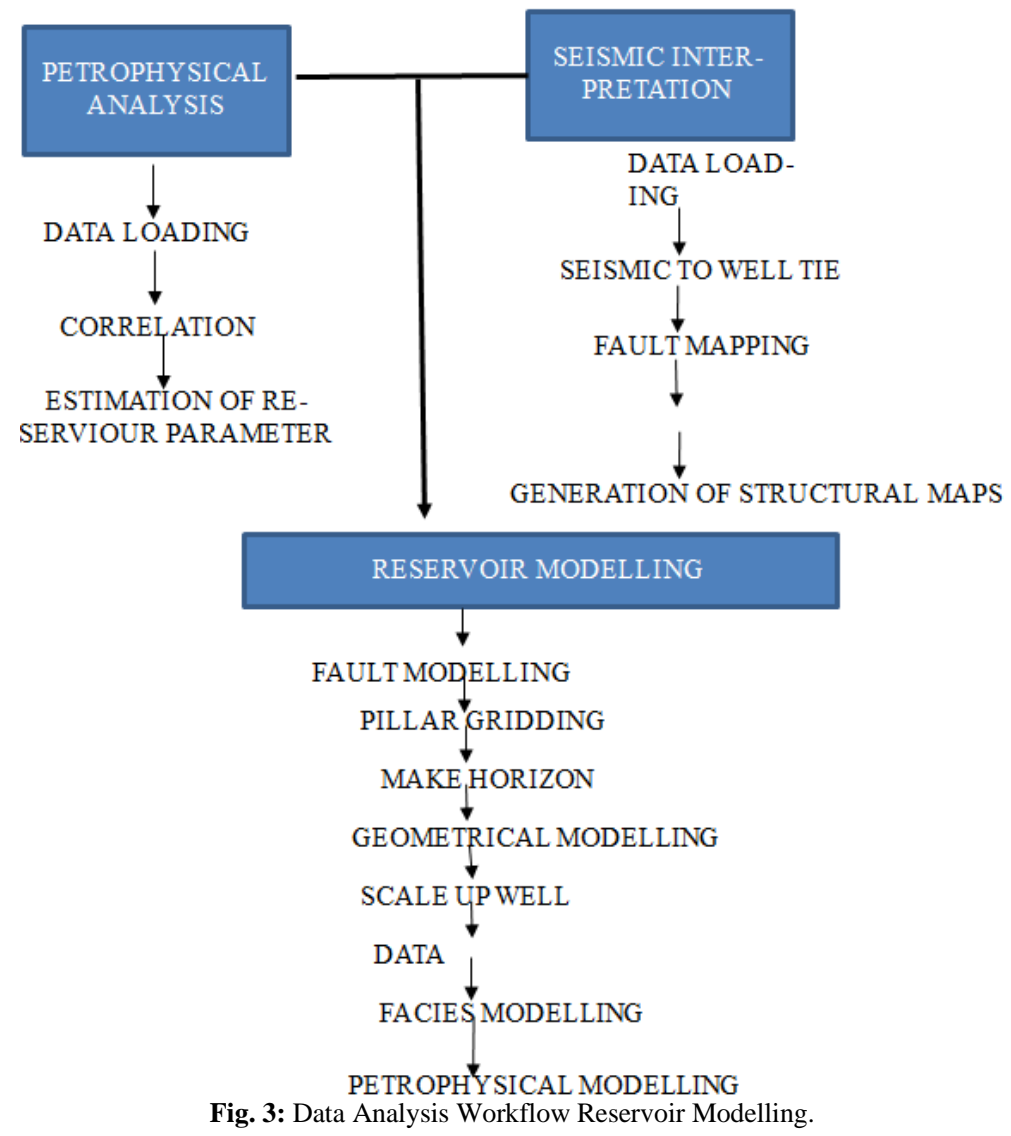

\subsection{Fault modelling, pillar gridding, zonation and layering}

Fault modelling is the process where the geometry of faults is defined. Faults are mapped on seismic section and are converted to fault sticks and are slightly extended (extrapolated) above and below reservoirs portion on seismic section in order to accommodate the geometry of the structures delineated.

The next process involves pillar gridding. A grid is formed by arranging a set of values into a regularly spaced array, commonly a square or rectangle, although other grid forms can also be used. The locations of the values represent the geographic locations in the area to be 
mapped and contoured. Gridding is the process of estimating the value of an attribute from isolated points into a regularly spaced mesh, called a grid. The attribute's values are estimated at each grid node.

The process starts with a set of rows and columns evenly spaced at the specified grid increment. At this point, the pillars are vertical lines passing through each row-column intersection. At the completion of pillar gridding, the skeletons (actually the pillars they represent) are not attached to any Z-values, nor do they represent any surface. They are only a set of pillars defining each grid cell's lateral shape and size in the 3-D model (Schlumberger, 2009).

Pillar gridding generated the 3-D grid skeleton/framework of the mid, top and bottom of the rock units under construction. Next, zones are created within the 3-D grid generated. This process is referred to as zonation. It is the process where the 3-D grid is separated into distinct stratigraphic intervals based on the vertical thickness (isochore) of the rock units within the wells. In order to further capture the finer stratigraphic/geological details of the field, the zones are further divided into layers. This is the process called layering. It caters for the existence of the shale laminae found within the reservoirs. It also helps to capture fine geological heterogeneities within the field by reducing the thickness of the cells which made up the 3-D grid.

\subsection{Up-scaling of well logs}

Up-scaling is the process where values are assigned to the cells penetrated by the well logs in the 3-D grid. Since each cell can only hold one value, the well logs must be averaged, i.e. up-scaled. The purpose is to be able to use the well information as input for the property modelling, i.e. for the distribution of property values between the wells (Schlumberger, 2009). Lithology, Resistivity, Porosity, Permeability and Water saturation are up-scaled into the 3-D grid using the arithmetic mean, most of these with the neighbour cells method. The quality of the up-scaled logs is checked using the inbuilt histogram in the software (PETRELTM workflow). This is achieved by comparing the raw logs with the up-scaled logs. When there are no large disparities between them. Therefore, the up-scaled logs are acceptable.

\subsection{Property modelling}

The next step involves property modelling. Property modelling is the distribution of reservoir rock properties in 3-D geocellular models using geostatistical principles. 3-D property modeling without adequate data analysis will result in idealistic models/realizations that have little or no correlation with geology. Therefore, a good understanding of the nature of the input data is central to meaningful property modelling. Adequate variogram analysis is made for each zone using the inbuilt data analysis module in the software.

\subsection{Geostatistical modelling}

Variogram Analysis

A variogram is a quantitative description of the variation of a property as a function of separation distance (lag). It is based on the assumption that the larger the separation distances of a dataset, the larger the variability. A variogram is needed as an input when a discrete property is populated using a stochastic algorithm. The mathematical definition of the variogram is:

(h) $=\frac{1}{2 m} \sum_{\mathrm{i}=1}^{\mathrm{m}}\left[\left(\mathrm{x}_{\mathrm{i}}\right)-\mathrm{Z}\left(\mathrm{x}_{\mathrm{i}}+\mathrm{h}\right)\right]^{2}$

Where $\mathrm{m}$ is the number of pairs of sample points of observations of the values of attribute $\mathrm{Z}$ separated by distance (lag) $\mathrm{h}$.

Ranking of Realizations

The five realizations of the properties modelled were ranked in other to choose the realization that is close to the control values using a statistical tool called Lp norm using the second order which is the least square method.

This method averages the deviation from the true value and estimate the error. The realization with the least error is taking as the best which can be used for further analysis. The expression is as stated below.

$\mathrm{L}_{\mathrm{p}}$ norm $=\sum_{\mathrm{n}=1}^{\infty} \frac{\left(\mathrm{d}_{\text {true }}-\mathrm{d}_{\text {realization }}\right)^{2}}{\mathrm{n}}$

\section{Results and discussion}

Wells 1, 2, 3 and 4 were correlated from the northwestern to the southeastern direction and a sand body was mapped across the correlated wells as shown in Figures 4. The well correlation panel showing the top and base of sand 1(Figure 4) shows that the sand body has varying proportion of sand and shale across the four wells. The thickness also varies across the wells, within a depth interval of $2510 \mathrm{~m}-$ $2547 \mathrm{~m}$ in well $1,2515 \mathrm{~m}-2535 \mathrm{~m}$ in well $2,2490 \mathrm{~m}-2530 \mathrm{~m}$ in well 3 and $2502 \mathrm{~m}-2530 \mathrm{~m}$ in well 4 . It is thickest in well 3 and thinnest in well 2. The table of petrophysical parameters estimated for sand 1 is shown in Table 1 . Seismic to well tie was done and horizons were mapped in other to be able to capture the lateral extent of the reservoir. 
NW

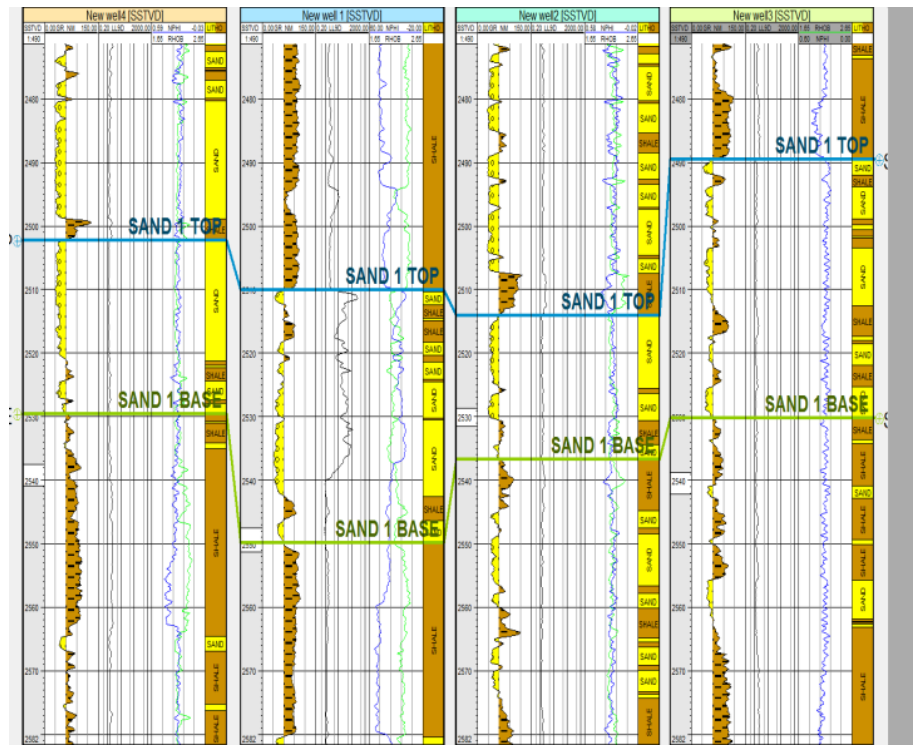

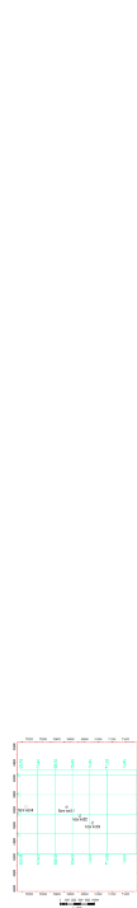

Fig. 4: Well Correlation Panel Showing the Top and Base of Sand 1

Table 1: Petrophysical Parameters for Sand 1

\begin{tabular}{|c|c|c|c|c|c|c|c|c|c|}
\hline SAND 1 & Gross (m) & Net (m) & $\begin{array}{l}\text { Net Pay } \\
(\mathrm{m})\end{array}$ & N/G & $\varnothing$ (frac. ) & $\mathrm{K}(\mathrm{mD})$ & Vsh & Sw & Sh \\
\hline WELL 1 & 38.65 & 27.83 & 22.59 & 0.72 & 0.25 & 1318 & 0.07 & 0.24 & 0.76 \\
\hline WELL 2 & 17.76 & 14.71 & 0.00 & 0.83 & 0.19 & 952 & 0.35 & 0.85 & 0.15 \\
\hline WELL 4 & 27.57 & 24.32 & 0.00 & 0.88 & 0.28 & 2900 & 0.02 & 0.82 & 0.18 \\
\hline
\end{tabular}

The horizon was then converted to surface to obtain time structural map as shown in Figures 5. The time structural map of the top of sand 1 as shown in Figure 4 depicts the variation in two way time(TWT) across the field. The TWT has a range of 2220 to $3000 \mathrm{~ms}$ and there is structural high that span from the central to the northern part of the field. Two faults approximately trending west-east and a four way closure are present which forms the trapping system within the field. These structures are excellent targets for hydrocarbon exploration (Abe et al., 2016). The existing wells were drilled at the flank of the structural high. The depth structural map of sand 1 is shown in Figure 6 and the structures on the time map are also evident on the depth map because there is no significant lateral change in velocity.

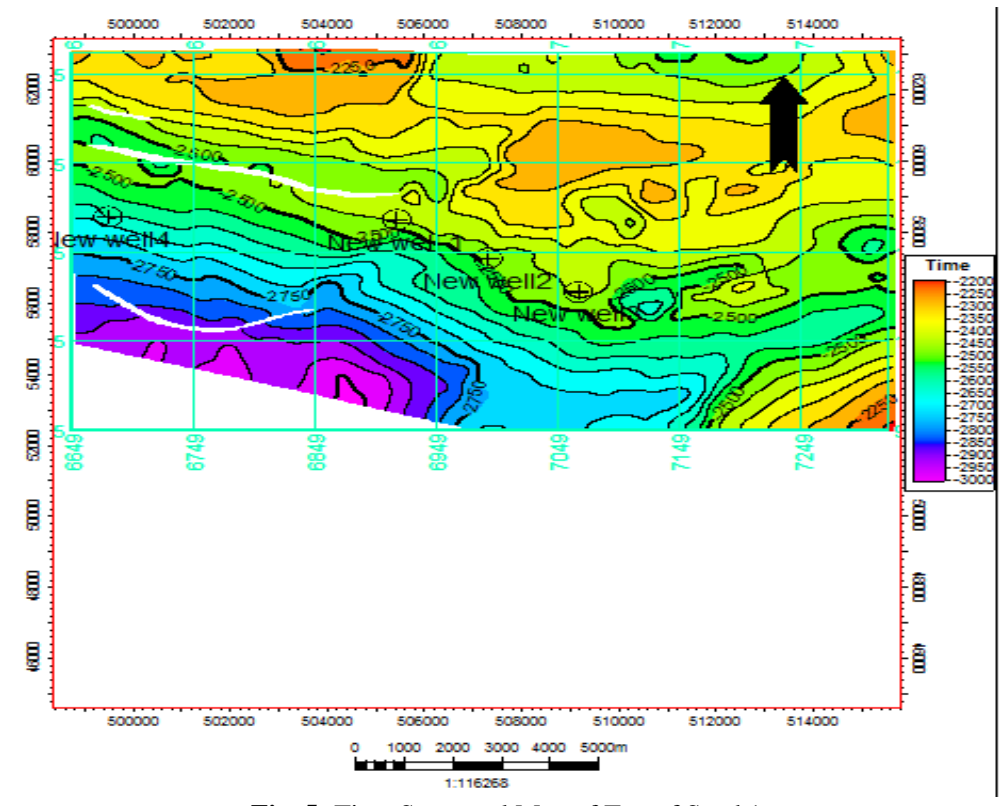

Fig. 5: Time Structural Map of Top of Sand 1. 


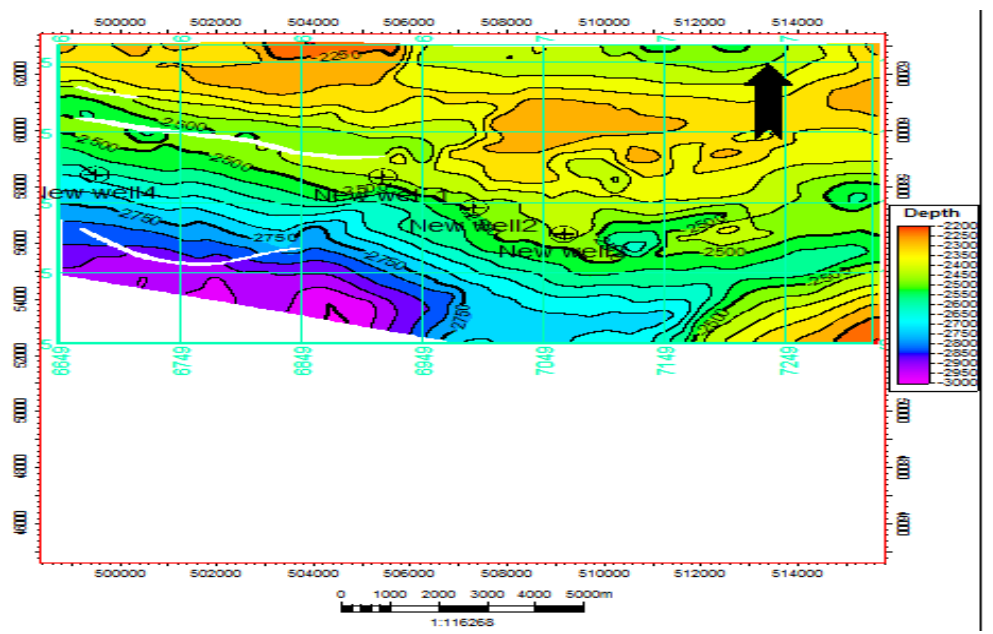

Fig. 6: Depth Structural Map of Top of Sand 1.

\section{Reservoir modelling}

Reservoir parameters like total porosity, effective porosity, volume of shale, net to gross, permeability and water saturation together with lithology were modelled stochastically and five iterations were generated for each in order to capture subsurface heterogeneity, but figures for only two realizations are presented in this paper. Variogram analysis was done and the results were favourable, after data transformation the nuggets were close to 0 , while the sills were close to 1 . The results of the quality check between the histogram plot of the upscalled cells and the raw logs were found to be appropriate for all the models generated.

\subsection{Lithology model for sand 1}

Figure 7 is the first realization of the model of Facies distribution for sand 1, the percentage of sand is $75.65 \%$ and shale is $24.35 \%$. Figures 8 , is the 2 nd realization of the Facies model generated for sand 1 . The two realizations showed variation in the distribution of sand and shale within the field which actually captured subsurface heterogeneity. The shale (brown) are aligned approximately northeastsouthwest. In the first realization, we have a cluster of shale towards the eastern and the central part of the field compared to what we have in the second realization.

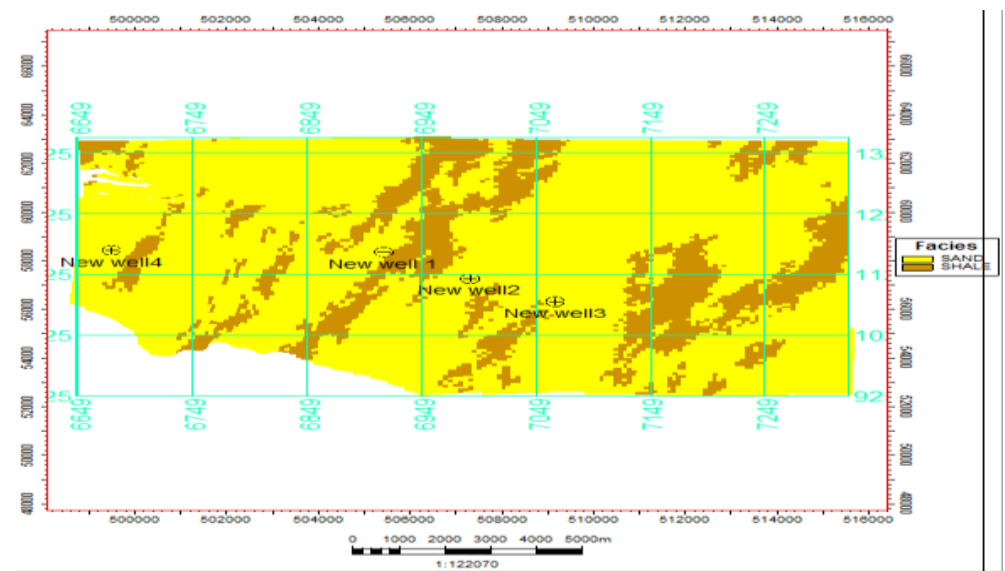

Fig. 7: Model of Facies Distribution in Sand 1(1st Realization).

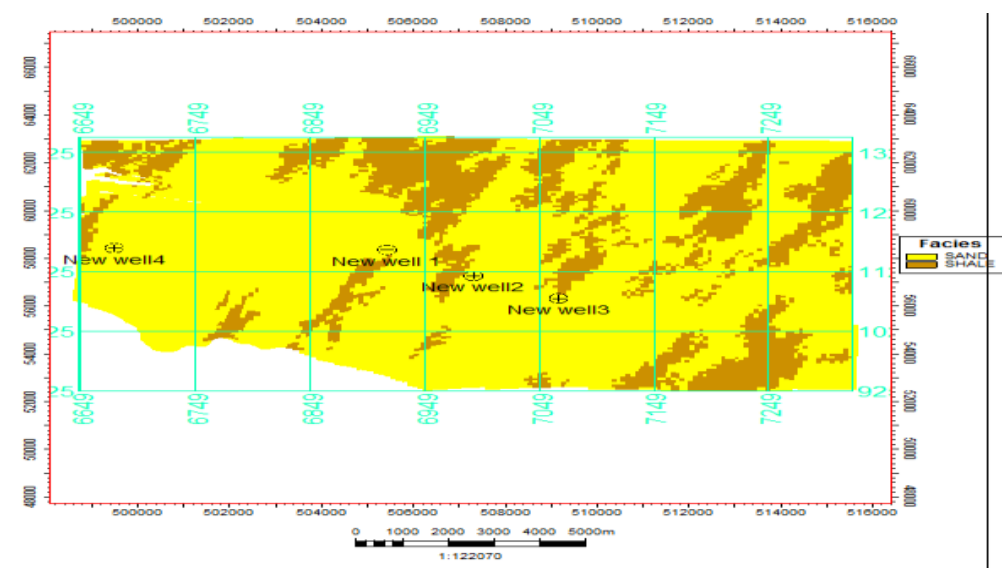

Fig. 8: Model of Facies Distribution in Sand 1(2nd Realization). 


\subsection{Effective porosity model for sand 1}

The first realization of effective porosity model for sand 1 in Figure 9 showed the variation of effective porosity across the field. High effective porosity regions were coloured yellow and red, the existing well locations coincide with areas with high effective porosity. High effective porosity clusters are found towards the western part of the field. The second realization of the effective porosity model in Figures 10 showed different distribution of effective porosity compared to the first realization. The second realization showed low effective porosity (pink) extending from the central to the southern part of the field, with the high porosity scattered randomly. The effective porosity around wells 4 and 1 are higher than the values in wells 2 and 3 . These variations are a reflection of the heterogeneities that occur within the subsurface. Effective porosity values were extracted at well locations for the realizations and shown in Table 2, the second realization was close to the control values estimated from well logs.

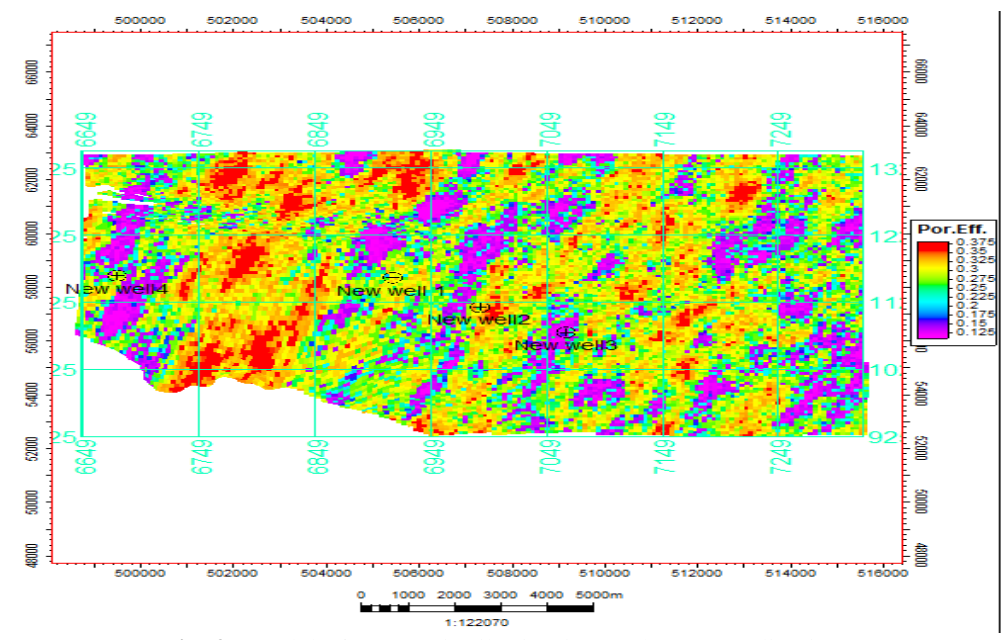

Fig. 9: Model of PHIE Distribution in Sand 1(1st Realization).

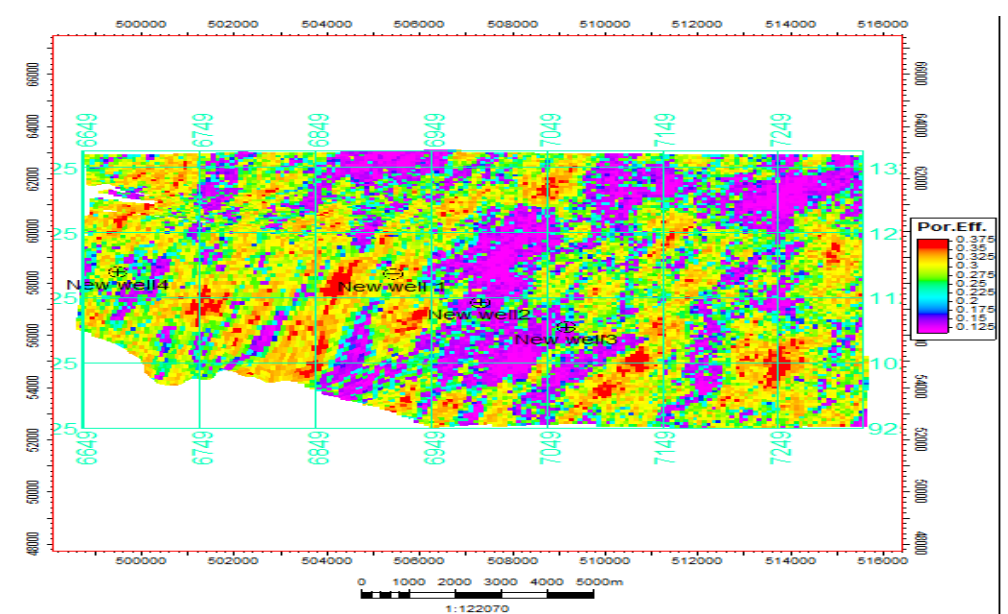

Fig. 10: Model of Eff. (Por.) Distribution in Sand 1(2nd Realization).

Table 2: Effective Porosity Values At Well Locations for the 2 Realizations and the Control

\begin{tabular}{lllll}
\hline Eff. Por. & WELL 1 & WELL2 & WELL3 & WELL4 \\
\hline $1^{\text {st }}$ Realization & 0.31 & 0.30 & 0.16 & 0.27 \\
$2^{\text {nd }}$ & 0.28 & 0.17 & 0.15 & 0.25 \\
Realization & 0.25 & 0.19 & 0.31 & 0.28 \\
CONTROL & & & & \\
\hline
\end{tabular}

\subsection{Total porosity model for sand 1}

Figure 11 is the first realization of the total porosity model for sand 1 and it shows variation in total porosity across the field. Wells 4,1 and 2 were drilled in areas of high total porosity compared to well 3. High porosity values dominate the field for this first realization with cluster of low porosity values around well 3 and extending southward.

The second realization in Figures 12 also showed variations with clusters of pink (low total Porosity) in the northeastern and northern portion of the field, thereby portraying the subsurface reality. The difference in the distribution of the total porosity values in the two realizations generated shows the reality of subsurface heterogeneity which could be as a result of structural or stratigraphic changes. The numerical values extracted from well locations for the two realizations are shown in Table 3 and the first realization values are close to the petrophysical values estimated from well logs. 


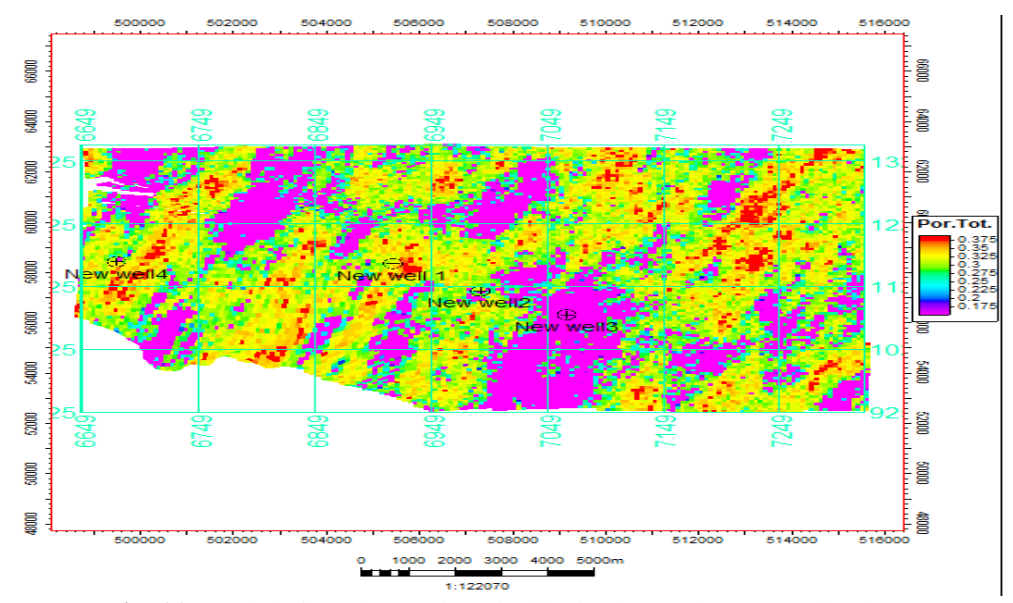

Fig. 11: Model of Total Porosity Distribution in Sand 1(1st Realization).

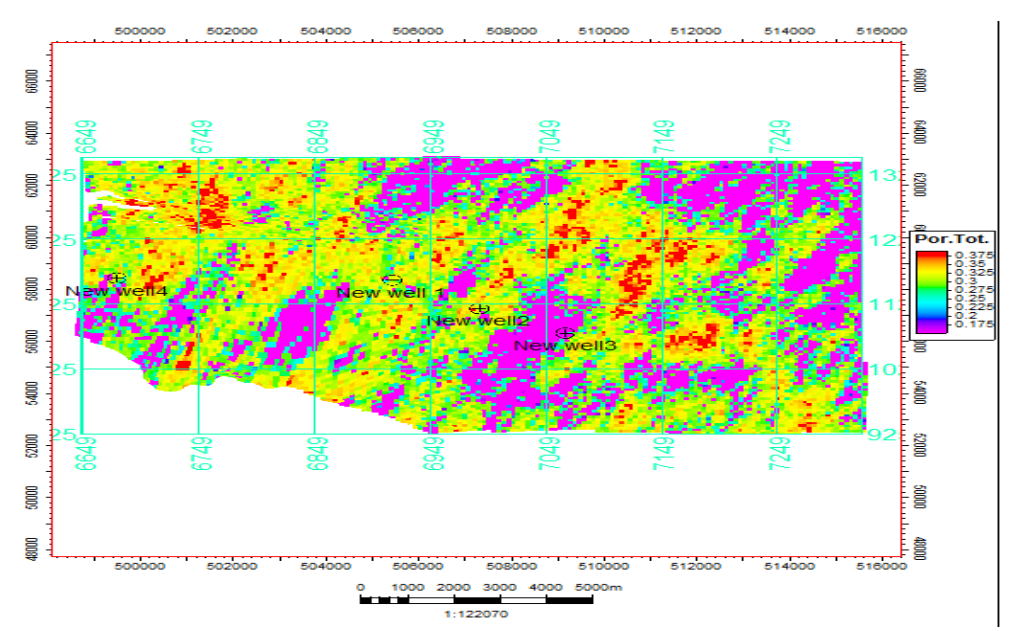

Fig. 12: Model of T. (Por.) Distribution in Sand 1(2nd Realization).

Table 3: Total Porosity Values at Well Locations for the 2 Realizations and the Control

\begin{tabular}{lllll}
\hline PHIDF & WELL 1 & WELL2 & WELL3 & WELL4 \\
\hline $1^{\text {st }}$ Realization & 0.32 & 0.18 & 0.15 & 0.21 \\
$2^{\text {nd }}$ & 0.24 & 0.19 & 0.16 & 0.26 \\
Realization & 0.25 & 0.19 & 0.31 & 0.28 \\
CONTROL & & & & \\
\hline
\end{tabular}

\subsection{Volume of shale model for sand 1}

The volume of shale was also modelled across the field in order to populate the reservoir parameters away from well bore.

The first realization of the volume of shale model is shown in Figure 13 and it shows the distribution of volume of shale within the field. Low volume of shale values are expected within an hydrocarbon bearing reservoir, because a good reservoir must be porous and permeable and the higher the volume of shale, the lower the porosity and the lower the reservoir quality. In this realization, wells 4 and 1 were drilled in areas with very low volume of shale, while the other wells were drilled in areas with slightly high volume of shale.

The second realization is shown in Figures 14 with low volume of shale values towards the eastern part in the second realization; the existing well locations have fairly low volume of shale values. The values extracted from the well locations for the two realizations showed that the second realization values are close to the control values with a range of 0.035 to 0.1 . The numerical values of the volume of shale extracted at the well locations are shown in Table 4. It ranged from 0.035 to 0.1 and the second realization is close to the control. 


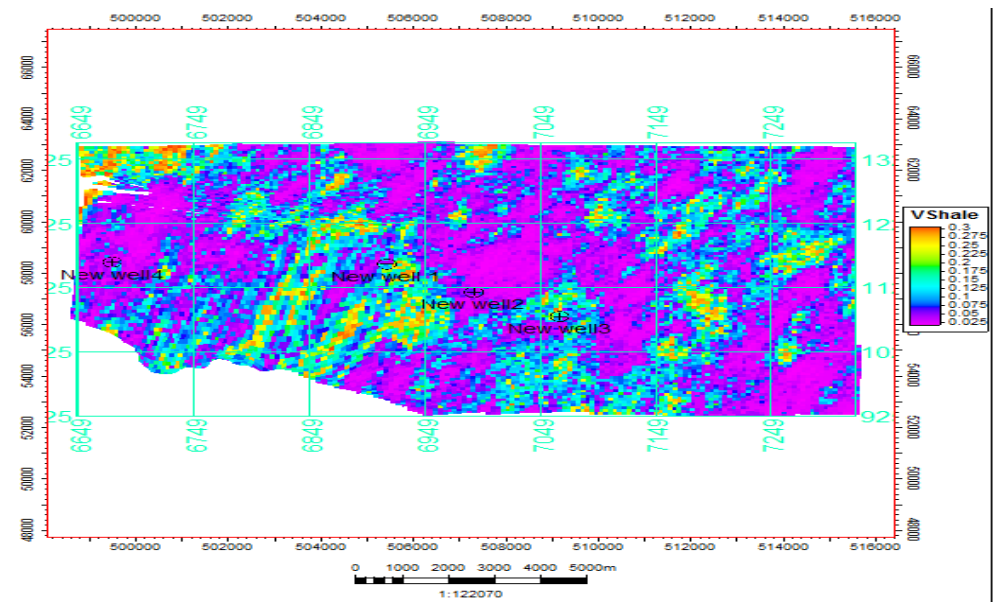

Fig. 13: Model of VSHF Distribution in Sand 1.

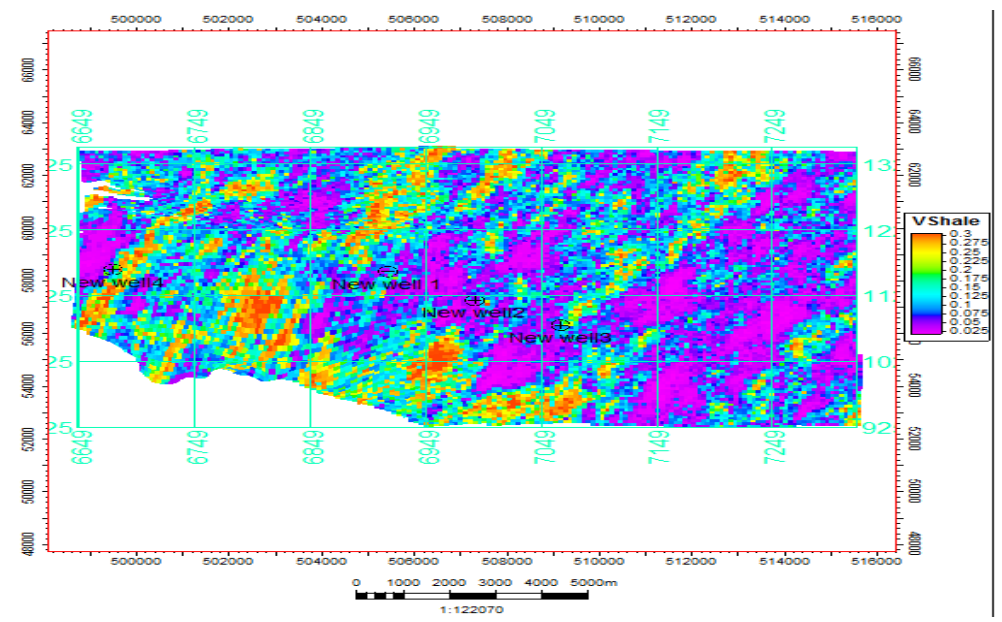

Fig. 14: Model of Vshale Distribution in Sand 1(2nd Realization).

Table 4: Volume of Shale Values at Well Locations for the 2 Realizations and the Control

\begin{tabular}{llllr}
\hline VSHF & WELL 1 & WELL2 & WELL3 & 0.175 \\
\hline $1^{\text {st }}$ Realization & 0.05 & 0.07 & 0.025 \\
$2^{\text {nd }}$ Realization & 0.04 & 0.035 & 0.1 & 0.075 \\
CONTROL & 0.07 & 0.35 & 0.32 \\
\hline
\end{tabular}

\subsection{Net to gross model for sand 1}

The first realization of the net to gross model in Figure 15 showed that wells 4,1 and 2 were drilled in areas with very net to gross values (red colour), while the location of well 3 has fairly high net to gross value. We have low net to gross values towards the eastern part while higher values dominate the western part.

In the second realization (Figure 16), the property was distributed in a different way with clusters of high values at the western and northeastern parts. The net to gross value is highest at the location of well 4 and lower in other well locations. The existing well locations coincide with areas having high net to gross values. Net to gross values extracted at the wells location for the two realizations in Table 5 showed the first realization ranging from 0.75 to 0.95 and the second realization with a range of 0.82 to 0.92 ,. The second realization is close to the control values estimated petrophysically. 


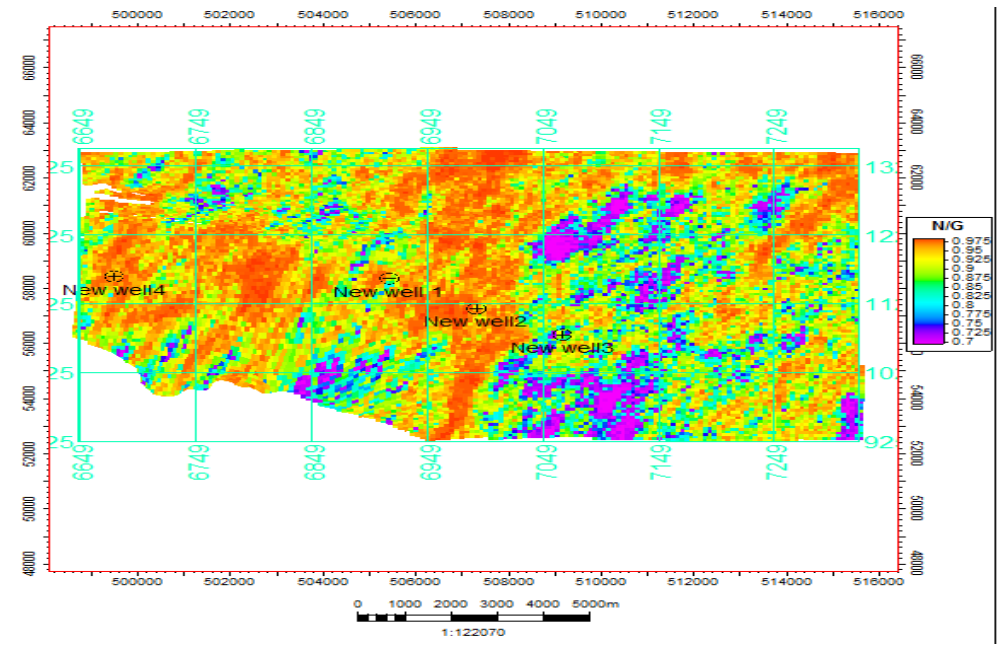

Fig. 15: Model of NTG Distribution in Sand 1(1st Realization).

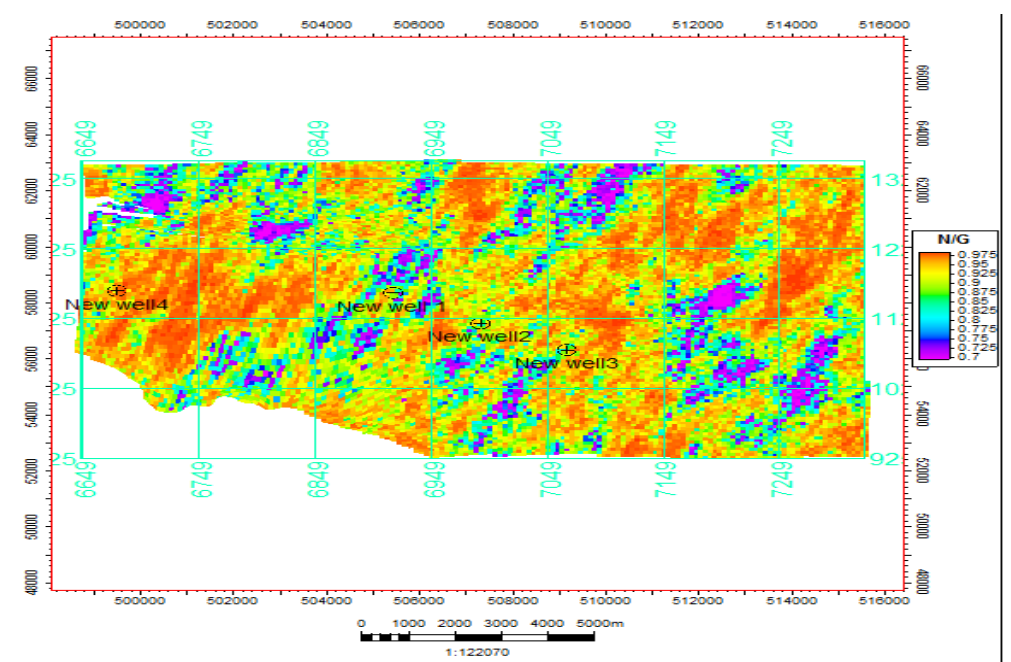

Fig. 16: Model of N/G Distribution in Sand 1(2nd Realization).

Table 5: Net to Gross Values at Well Locations for the 5 Realizations and the Control

\begin{tabular}{llll}
\hline NTG & WELL 1 & WELL2 & WELL3 \\
\hline $1^{\text {st }}$ Realization & 0.8 & 0.75 & 0.85 \\
$2^{\text {nd }}$ Realization & 0.82 & 0.85 & 0.88 \\
CONTROL & 0.72 & 0.83 & 0.92 \\
\hline
\end{tabular}

\subsection{Permeability model for sand 1}

The direct relationship between porosity and permeability was used as a basis for generating the model. Permeability and porosity values were crossplotted as shown in Figure 17 to obtain a linear equation generated from least square method given as

PERMF_vs_PHIDF $=(\mathrm{Y}=53209.5 * \mathrm{X}-7965.53)$

Where $\mathrm{Y}$ is the permeability and $\mathrm{X}$ is the porosity

This equation was then used with the initial porosity model to generate the permeability model in Figure 18 . The model shows the variation in permeability across the field, the existing well locations were drilled in areas having high permeability.

\subsection{Water saturation model for sand 1}

A function was generated as shown in Figure 19 by plotting water saturation against height obtained from the statistics tab of the above contact, this function was then multiplied with the above contact to generate water saturation model shown in Figure 20.

The model showed the variation of water saturation across the field with high values spanning from the center to the southern part, the existing well locations were drilled at the flank of the structural high initially identified from the structural map and having low water saturation with corresponding high hydrocarbon saturation.

In addition to the existing well locations, two drillable points (prospects) were proposed by considering the all the initial petrophysical property models and the parameters of the two points named P1 and P2 is shown in Table 6. P1 has total porosity of 0.28 , effective porosity of 0.19 , net to gross 0.88 , and permeability of $3500 \mathrm{mD}$, volume of shale of 0.09 and hydrocarbon saturation of $80 \%$. P2 has total porosity of 0.31 , effective porosity of 0.25 , net to gross of 0.93 , permeability of $4000 \mathrm{mD}$, volume of shale of 0.03 and hydrocarbon saturation of $60 \%$. 


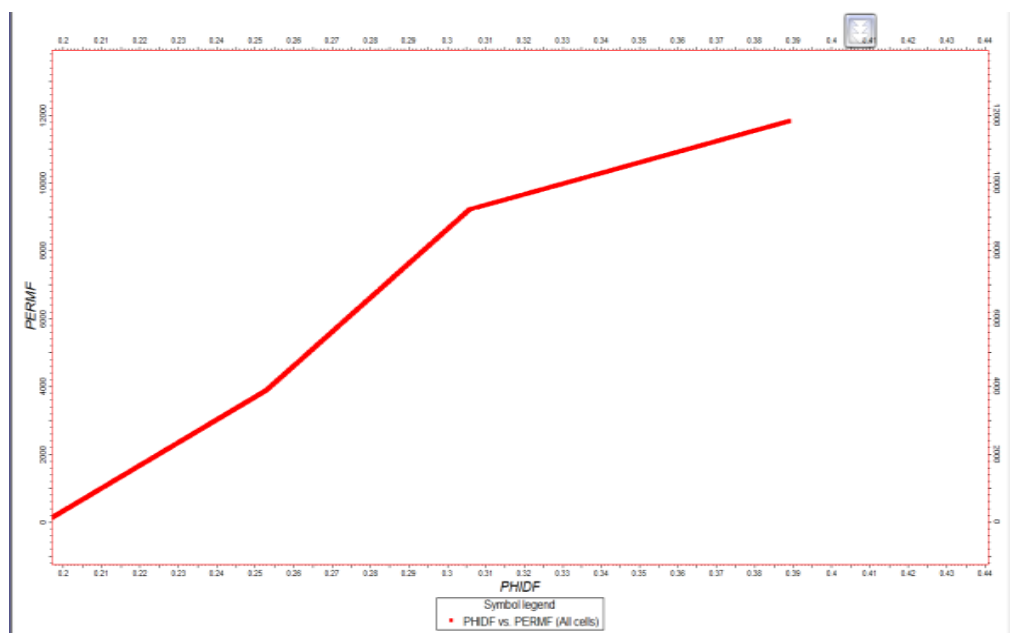

Fig. 17: Crossplot of Permeability and Total Porosity.

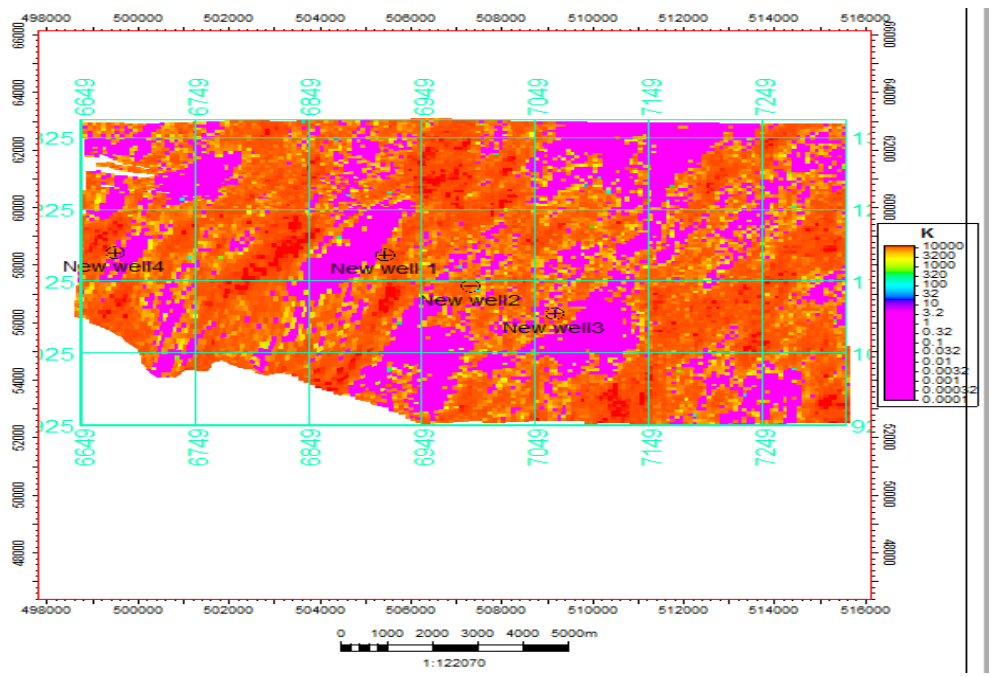

Fig. 18: Model of Permeability Distribution in Sand 1.

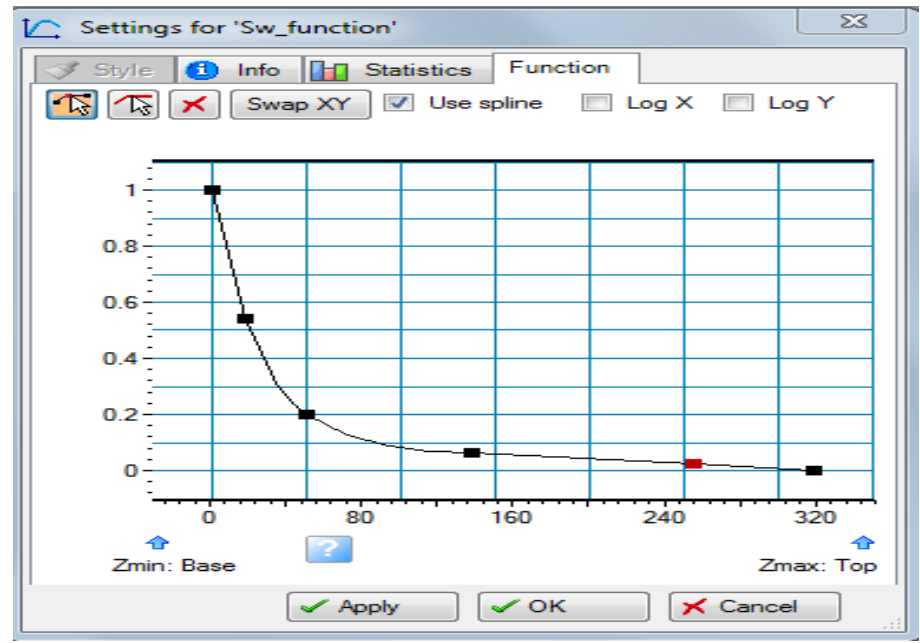

Fig. 19: Crossplot of $\mathrm{Sw}$ and Above Contact. 


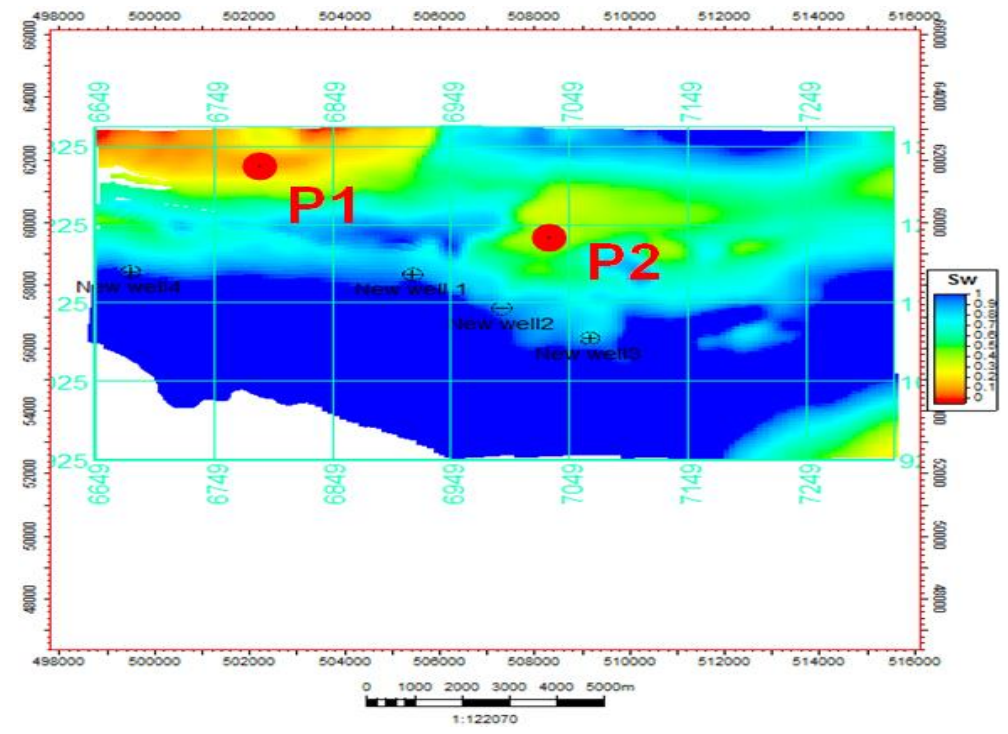

Fig. 20: Model of Water Saturation Distribution in Sand 1.

Table 6: Petrophysical Values for Prospects $\mathrm{P} 1$ and $\mathrm{P} 2$

\begin{tabular}{|c|c|c|c|c|c|c|c|c|}
\hline SAND 1 & LITHO & PHIE & PHIDF & $\mathrm{N} / \mathrm{G}$ & $\mathrm{K}(\mathrm{mD})$ & Vsh & Sw & $\mathrm{Sh}$ \\
\hline P 1 & SAND & 0.28 & 0.19 & 0.88 & 3500 & 0.09 & 0.2 & 0.8 \\
\hline $\mathrm{P} 2$ & SAND & 0.25 & 0.31 & 0.93 & 4000 & 0.03 & 0.4 & 0.6 \\
\hline
\end{tabular}

\section{Conclusion}

The Facies modelling of sand 1 showed different distribution of sand and shale within the field for the two realizations with the existing well locations cited on where we have sand deposit.

The two realizations of the effective porosity model generated for sand 1 gave different distribution of effective porosity values. The values at the existing well locations are favourable for a good reservoir and high effective porosity values represented by yellow and red colour are more evident on the first realization. Numerical values extracted at the well locations for the two realizations gave various values with the second realization having values that are close to that of the control. Total porosity models generated for the two realizations gave different results with wells 4 and 1 coinciding with where we have high effective porosity. Volume of shale values vary from one realization to the other in the models generated, areas where we have high porosity are equivalent to low volume of shale areas and the existing well locations are well favoured by the distribution. The second realization values at the existing well locations were close to the control values obtained from the petrophysical analysis. The net to gross models showed the distribution of the property, with high net to gross values dominating the surface. Existing well locations have high net to gross values and the second realization values are close to that of the control.

The permeability model generated for sand 1 also showed the distribution of permeability on the model with the existing well locations having high permeability values and the water saturation model generated confirmed the reason for drilling the existing wells at the flank of the structural high because it has low water saturation values meaning that it actually contains hydrocarbon.

\section{References}

[1] Abe, S.J and Olowokere, M.T. (2013). Structure and Facies Development Resulting From Neogene Gravity Tectonics and Depositional Processes:Application to Afo Field Niger Delta, Nigeria. Journal of Emerging Trends in Engineering and Applied Sciences (JETEAS) 4(3): 541-544.

[2] Abe, S. J.,, Ayuk M. A.,, Ojo B. T., Oluwadare O. and Olowokere M. T., (2016), A Study of Seismic Hydrocarbon Indicators.

[3] Over " $X$ " Field, Niger Delta. Journal of Basic and Applied Research International, 16(3): 202-210.

[4] Abrahamsen P, Omre H and Lia O (1991) Stochastic Models for Seismic Depth conversions and Geological Horizons. SPE 23138, Offshore Europe, Aberdeen. https://doi.org/10.2118/23138-MS

[5] Adesida A and Ehirim, BO (1988) Cenozoic Niger Delta: A guide to its lithosedimentary analysis. SPDC Exploration note 88.002 (Ref: on-shore wells). 1-10.

[6] Avbovbo AA (1978). Tertiary lithostratigraphy of Niger Delta, American Association of Petroleum Geologist Bulletin. 62 (2): 295-300 https://doi.org/10.1306/C1EA482E-16C9-11D7-8645000102C1865D.

[7] Aizebeokhai AP, Olayinka I (2011) Structural and stratigaphic mapping of Emi Field, offshore Niger Delta. J Geol Min Res 3(2):25-38.

[8] Ejedawe JE Coker SJL., Lambert-Aikhionbare, DO, Alofe KB., and Adoh FO (1984) Evolution of oil-generative window and oil and gas occurrence in Tertiary Niger Delta Basin: American Association of Petroleum Geologists. (68): 1744-1751. https://doi.org/10.1306/AD46198F-16F711D7-8645000102C1865D.

[9] Damsleth E and L Holden (1994) Mixed reservoir characterization methods. SPE centennial petroleum engineering symposium, Proceedings, Tulsa, Oklahoma. https://doi.org/10.2118/27969-MS.

[10] Doust H and Omatsola E(1990) Niger Delta," In: J. D. Ed- wards and P. A. Santogrossi, Eds., Divergent/Passive Margin Basins, AAPG Memoir, Vol. 48, No. 1, pp. 239-248.

[11] Doyen PM (1988) Porosity from Seismic Data;' Geophysics, 53, pp. 1263-1275. https://doi.org/10.1190/1.1442404.

[12] Dubrule O (1988) A review of Stochastic Models for Petroleum Reservoirs. Brith. Sot. Res. Geol. Meeting on Quantifications of Sediment Body Geometries and Their Internal Heterogeneities. https://doi.org/10.1007/978-94-015-6844-9_38.

[13] Frankl E J and Cordy EA (1967) The Niger Delta oil province: Recent developments, onshore and offshore, Mexico city, seventh world petroleum congress proceedings. (2): 195209.

[14] Geoff B (2005) Stochastic Simulation and Reservoir Modelling Workflow. C \&PE 940. Kansas Geological Survey.

[15] Gongquan L, Gongyang C, Dongsheng W(2006) Spatial data mining technology in oil and gas reservoir modeling . Journal of petroleum and natural gas (Jianghan Petroleum Institute), vol.28 (4): 47-49. 
[16] Haldorsen H and Damsleth E, (1990) Stochastic modeling; JPT, pp. 404-412. https://doi.org/10.2118/20321-PA.

[17] Hami-Eddine, K., Klein, P., Loic, R., Ribet, B., Grout, M. (2015). A new technique for lithology and fluid content prediction from prestack data: An application to carbonate reservoir. pp. 1 https://doi.org/10.1190/INT-2014-0049.1.

[18] Jegede, E., Ako, B. D., Adetokunbo, P., Edigbue, P., Abe, S. J. (2014) Seismic stratigraphy and attribute analysis of an offshore field,

[19] Niger Delta, Nigeria. Arabian Journal of Geosciences, https://doi.org/10.1007/s12517-014-1665-7.

[20] Joumel A G and Alabert F G (1990) New Methods for Reservoir Modeling;' JPT, pp. 212-218. https://doi.org/10.2118/18324-PA.

[21] Lia O, Omre H, Tjelmeland H and Holden L(1995) The Great reservoir uncertainty study - Grus," in Profit project summary reports, eds . Norwegian Petroleum Directorate, pp 191-206.

[22] Omre H (1991) Stochastic Models for Reservoir Characterization. Chapter in: Recent Advances in Improved Oil Recovery Methods for North Sea Oil Sandstone Reservoirs, eds Norwegian Petroleum Directorate.

[23] Omre H, Tjelmeland H QY and Hinderaker L (1991). Assessment of Uncertainty in the Production Characteristics of a Sand Stone Reservoir; Proc. Niper DOE Third Intern. Res. Char. Tech. Conf., Tulsa, Oklahoma.

[24] PetroWiki (2016) Geostatistical reservoir modelling. Published by Society of Petroleum Engineers Petrowiki.org/Geostatistical_reservoir_modelling. (Accessed on 18th September, 2017).

[25] Qihong, Song Z, Chengqian T (2000) Reservoir description of the stochastic simulation method. Journal of Xi'an Petroleum Institute (NATURAL SCIENCE EDITION), vol.15 (1): 13-16.

[26] Reijers TJF (1996) Selected Chapters on Geology, SPDC of Nigeria, Copporate Reprographic Services, Warri. 197. https://doi.org/10.1023/A:1003089529914.

[27] Schlumberger Oilfield Services presentation at the IHS CERA Week conference in February 2009.

[28] Short KC and Stauble A J (1967) outline of the geology of Niger Delta, American

[29] Tyler K. J, Svanes T, Omdal S (1993) Faster History Matching and Uncertainty in Predicted Production Profiles With Stochastic Modeling. 68th Annual Technical Conference and Exhibition of the Society of Petroleum Engineers, Houston, Texas 3-6, SPE 26420. https://doi.org/10.2118/26420-MS

[30] Xiangyang H, Xiong Q, Shenghe W (2001) Reservoir modeling method research progress. Journal of Petroleum University (NATURAL SCIENCE EDITION), vol. 25 (1): 107-112

[31] Xingyao Y, Weisheng H, Huang X (2005) Bayesian sequential Gauss simulation method [J]. Journal of Petroleum University (NATURAL SCIENCE EDITION), vol.29 (5): 28-3

[32] Zhenfeng L, Tianyao H, Changchun Y (2003) Sedimentary model and reservoir stochastic modeling of [J].geophysics progress, vol.18 (3): 519523. 